\title{
Photosynthetic Characteristics of Resistance and Susceptible Lines to High Temperature Injury in Panax ginseng Meyer
}

\author{
Joon Soo Lee*, Dong Yun Lee, Jang Ho Lee, In Ok Ahn, and Jun Guy In \\ Ginsneg Resources Research Laboratory, R\&D Headquarters, Korea Ginseng Corporation, Daejeon 305-345, Korea
}

In this study, photosynthetic parameters such as the net photosynthesis rate, stomatal conductance, intercellular $\mathrm{CO}_{2}$ concentration, and transpiration rate were examined in selected ginseng varieties and/or lines that are resistant (Yunpoong, HTIR 1, HTIR 2, and HTIR 3) and susceptible (Chunpoong) to high temperature injury (HTI). The net photosynthesis rate increased with the increase in the light intensity in all the HTI-resistant and -susceptible ginseng lines with a light saturation point of $200 \mu \mathrm{mol}$ $\mathrm{m}^{-2} \mathrm{~s}^{-1}$, except for Yunpoong that had a light saturation point of $400 \mu \mathrm{mol} \mathrm{m} \mathrm{m}^{-2}$. At the light saturation point, the net photosynthesis rate in July was highest in HTIR 3, at $4.2 \mu \mathrm{mol} \mathrm{CO} \mathrm{m}^{-2} \mathrm{~s}^{-1}$, and was lowest in Yunpoong, HTIR 1, Chunpoong, and HTIR 2, in that order, at 1.9 to $3.7 \mu \mathrm{mol} \mathrm{CO} \mathrm{m}^{-2} \mathrm{~s}^{-1}$. The net photosynthesis rate in August was highest in Yunpoong at $5.9 \mu \mathrm{mol} \mathrm{CO}_{2} \mathrm{~m}^{-2} \mathrm{~s}^{-1}$, and lowest in HTIR 1 and HTIR $3\left(4.5 \mu \mathrm{mol} \mathrm{CO} \mathrm{Cm}^{-2} \mathrm{~s}^{-1}\right)$ and in other lines, in that order, at 2.8 to $2.9 \mu \mathrm{mol} \mathrm{CO}_{2} \mathrm{~m}^{-2} \mathrm{~s}^{-1}$. The stomatal conductance in July was highest in HTIR $3\left(0.055 \mathrm{~mol} \mathrm{H}_{2} \mathrm{O} \mathrm{m}^{-2} \mathrm{~s}^{-1}\right)$ and Yunpoong, Chunpoong, HTIR 1, and HTIR 2 were 0.038, 0.037, 0.031, and 0.017 in that orders. In August, meanwhile, HTIR 1 showed the highest as 0.075 , and followed by HTIR 3, Chungpoong, and HTIR 2 with 0.070, 0.047, and 0.023, respectively. The intercellular $\mathrm{CO}_{2}$ concentration at the light saturation point in July and August was much lower in HTIR 2 at 139 and $185 \mu \mathrm{mol} \mathrm{mol}^{-1}$ than in the other ginseng lines at 217 to 257 and 274 to $287 \mu \mathrm{mol} \mathrm{mol}^{-1}$, respectively. The transpiration rate in July and August was higher in the HTI-resistant lines of Yunpoong, HTIR 1, and/or HTIR 3 at 0.83 to 1.03 and 1.67 to $2.10 \mathrm{~mol} \mathrm{H}_{2} \mathrm{O} \mathrm{m}^{-2} \mathrm{~s}^{-1}$ than in the other ginseng lines at 0.27 to $0.79 \mathrm{~mol} \mathrm{H}_{2} \mathrm{O} \mathrm{m}^{-2} \mathrm{~s}^{-}$ ${ }^{1}$ and $0.51-1.65 \mathrm{~mol} \mathrm{H}_{2} \mathrm{O} \mathrm{m}^{-2} \mathrm{~s}^{-1}$, respectively. Conclusively, all the photosynthetic parameters that were examined in this study were generally higher in the HTI-resistant ginseng lines than in the HTI-susceptible lines, except for HTIR 2, and were much higher in August than in July, especially in the resistant ginseng lines. All these results can be used to provide basic information for the selection of HTI-resistant ginseng lines and the application of cultural practices that are efficient for ginseng growth, based on the photosynthetic characteristics of the lines.

Keywords: Panax ginseng, High temperature injury, Photosynthesis, Stomatal conductance, Transpiration

\section{INTRODUCTION}

Plants produce chemical energy through photosynthesis using light and $\mathrm{CO}_{2}$ under favorable temperature conditions. Such chemical energy is used to synthesize and accumulate organic materials such as starch, proteins, and lipids for plant growth. Ginseng (Panax ginseng Meyer) is a semi-shade perennial plant whose photosynthetic capability is reduced at a light intensity and temperature that are beyond the optimum conditions, which adversely affects the growth and development of the plant's aboveground and underground parts. This requires the shielding of ginseng plants from direct sunlight by shading them during their growth in fields. In this sense, scattered (c) This is an Open Access article distributed under the terms of the Creative Commons Attribution Non-Commercial License (http://creativecommons.org/licenses/by-nc/3.0/) which permits unrestricted non-commercial use, distribution, and reproduction in any medium, provided the original work is properly cited.
Received 22 Feb. 2011, Revised 31 Aug. 2011, Accepted 01 Sep. 2011

*Corresponding author

E-mail: cbmleejs@kgc.or.kr

Tel: +82-42-870-3133, Fax: +82-2-42-870-3117 
indirect light, which dominates in somewhat cloudy days, would be better for the photosynthesis of ginseng than intensive direct light in sunny days [1,2].

Temperature and light intensity are very significantly correlated in the photosynthesis of ginseng, and show the optimum light intensities of $11,000 \mathrm{Lux}$ at $15^{\circ} \mathrm{C}$ to $20^{\circ} \mathrm{C}$ and $9,500 \mathrm{Lux}$ at over $25^{\circ} \mathrm{C}$ for maximum photosynthesis. The net photosynthesis of the ginseng plant is higher when it is shaded with a light transmission rate of $15 \%$ than with $5 \%$ and $30 \%$. The duration of the $\mathrm{CO}_{2}$ absorption increases with the increase in the light transmission rate under shading; $\mathrm{CO}_{2}$ absorption occurs at 9:00 a.m. under shading with a light transmission rate of $5 \%$ to $15 \%$, but occurs longer at 7:00 to 9:00 a.m. with a light transmission rate of $20 \%$. The $\mathrm{CO}_{2}$ saturation point is $600 \mathrm{ppm}$, and the compensation point is $130 \mathrm{ppm}$. The respiration rate increases with temperature increase. Especially for ginseng, the efficiency of the optimum photosynthesis is not influenced by either the temperature or the light intensity alone, but also by the interactions of the two factors [3].

Hyun et al. [4] reported that the photosynthetic capacities differed depending on the light intensity and the ginseng leaf temperature, which showed the maximum $\mathrm{CO}_{2}$ absorption at a light intensity of $250 \mu \mathrm{mol} \mathrm{m} \mathrm{m}^{-2} \mathrm{~s}$ ${ }^{1}$ and a leaf temperature of $18^{\circ} \mathrm{C}$, which was optimal for photosynthesis. Lee et al. [5] reported that, in their study to compare the photosynthetic characteristics of $P$. ginseng and $P$. quinquefolium, the optimum temperature for photosynthesis and the light saturation point were similar, at around $20^{\circ} \mathrm{C}$ and 15,000 Lux, respectively. The photosynthesis rate in P. quinquefolium $(7.8 \mathrm{mg}$ $\left.\left[\mathrm{CO}_{2} / \mathrm{dm}^{2} / \mathrm{h}\right]\right)$ was higher than in P. panax $\left(6-7 \mathrm{mg}\left[\mathrm{CO}_{2} /\right.\right.$ $\left.\mathrm{dm}^{2} / \mathrm{h}\right]$ ), though. In the examination of photosynthetic characteristics by Lee [6], the light saturation point and the optimum temperature for photosynthesis were similar at around $15,000 \mathrm{Lux}$ and $20^{\circ} \mathrm{C}$ in all the tested ginseng varieties and/or lines (Chunpoong, Yunpoong, Gopoong, and Jakyungjong). The net photosynthetic rates, however, were $6.0 \mathrm{mg}\left(\mathrm{CO}_{2} / \mathrm{dm}^{2} / \mathrm{h}\right)$ for Yunpoong, $5.0 \mathrm{mg}$ $\left(\mathrm{CO}_{2} / \mathrm{dm}^{2} / \mathrm{h}\right)$ for Chunpoong, and $5.0 \mathrm{mg}\left(\mathrm{CO}_{2} / \mathrm{dm}^{2} / \mathrm{h}\right)$ for Gopoong, which were somewhat higher than the $4.5 \mathrm{mg}$ $\left(\mathrm{CO}_{2} / \mathrm{dm}^{2} / \mathrm{h}\right)$ in Jakyungjong. Under the controlled light intensity of $500 \mu \mathrm{mol} \mathrm{m}^{-2} \mathrm{~s}^{-1}$ in Jakyungjong, the net photosynthesis rate, stomatal conductance, and intercellular $\mathrm{CO}_{2}$ concentration at different growth stages showed that all these parameters were related to the increase in the net photosynthesis rate in August rather than in July [7]. Oh et al. [8] reported that the net photosynthesis rate and stomatal conductance were higher in the front and middle rows than in the rear rows of ginseng beds, regardless of the ginseng growth stage. All these show that the net photosynthesis rate in ginseng is related to environmental conditions, shading materials, and cultivation methods, and these suggest that proper ginseng growth should be governed by cultural conditions for the plant's optimum net photosynthesis.

In this study, the net photosynthesis rate, stomatal conductance, intercellular $\mathrm{CO}_{2}$ concentration, and transpiration rate in selected ginseng lines that were resistant and susceptible to high temperature injury (HTI) were examined during their cultivation in the hot-temperature season (July to August) to provide basic information on the photosynthetic characteristics of the ginseng lines.

\section{MATERIALS AND METHODS}

Experiments were conducted in the experiment fields of the Natural Resources Research Institute of Korea Ginseng Corporation in Boeun, Korea, using ginseng varieties and/or lines that were resistant (Yunpoong, HTIR 1, HTIR 2, and HTR 3) and susceptible (Chunpoong) to HTI. On March 5, 2008, one-year-old seedling roots of these ginseng lines were transplanted in the main experiment field at a density of 54 plants ( 6 columns $\times 9$ rows) in a $1.62 \mathrm{~m}^{2}$ plot, and were cultivated under a shading sheet with a light transmission rate of $20 \%$ ( $80 \%$ shade). A two-layered black polyethylene net was not additionally installed during the 2- to 3-year ginseng growth. Photosynthetic parameters such as the net photosynthesis rate, stomatal conductance, intercellular $\mathrm{CO}_{2}$ concentration, and transpiration rate were measured twice, on July 11 and August 14, 2009, with an LI 6400 Portable Photosynthesis System (Li-Cor, Lincoln, NE, USA) using the same leaves in the third rows of the plots. The conditions inside the leaf chamber were controlled by an air influx rate of $500 \mu \mathrm{mol} \mathrm{s}^{-1}, \mathrm{a} \mathrm{CO}_{2}$ concentration of $400 \mu \mathrm{mol}^{-1}$, a relative humidity of $30 \%$ to $40 \%$, and a temperature of $20^{\circ} \mathrm{C}$. To examine the effects of the light intensity on the photosynthetic parameters, they were measured by adjusting the photosynthetically active radiation to 0,200 , 400,600 , and $800 \mu \mathrm{mol} \mathrm{m}^{-2} \mathrm{~s}^{-1}$ using an LI-6400-02 LED light source (LI-COR).

\section{RESULTS AND DISCUSSION}

The net photosynthesis rates in the HTI-resistant and -susceptible ginseng lines increased with the increase in the light intensity and peaked at the light intensity of 200 $\mu \mathrm{mol} \mathrm{m} \mathrm{s}^{-2}$, without a significant increase in the net pho- 
A

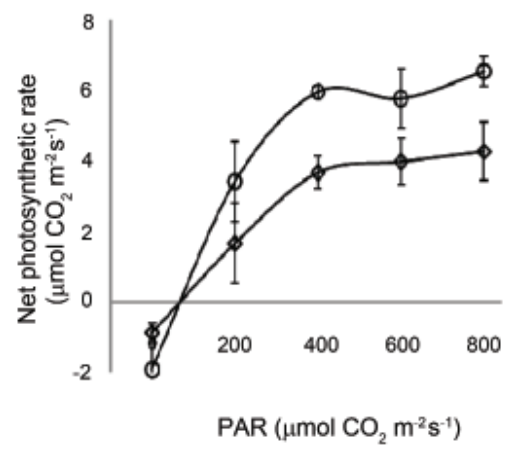

C

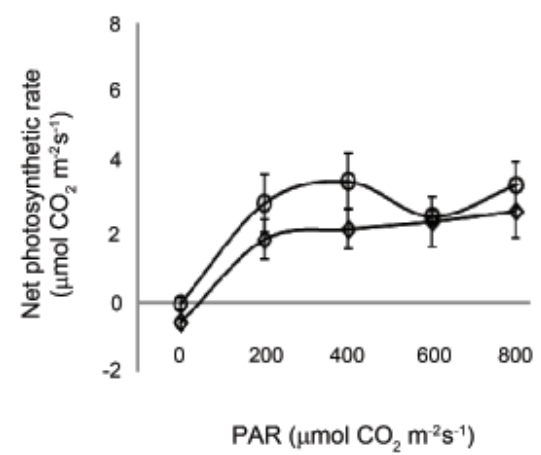

B

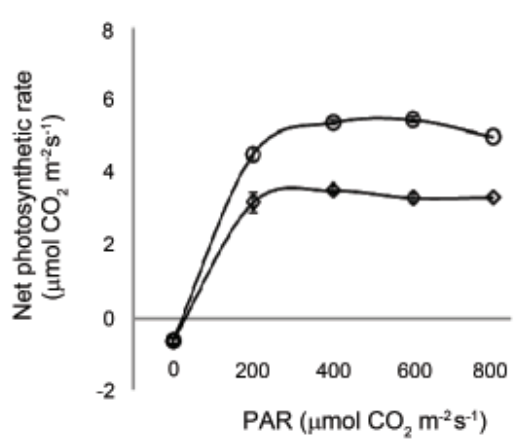

D

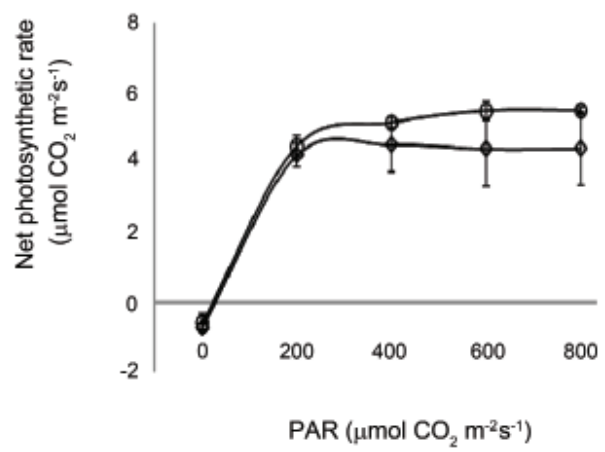

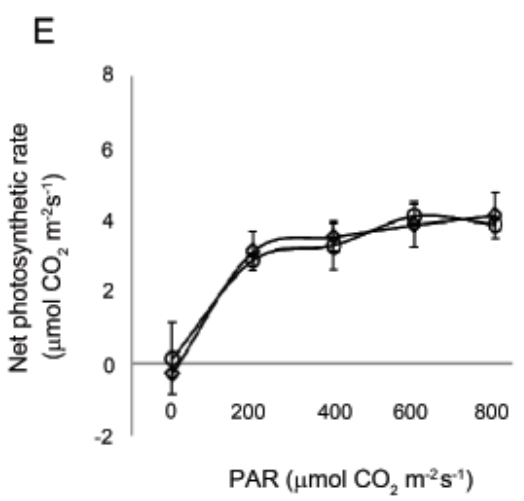

Fig. 1. Monthly net photosynthesis rates in the high temperature injury-resistant (A: Yunpoong, B: HTIR 1, C: HTIR 2, and D: HTIR 3), susceptible (E: Chunpoong) lines. The bars represent the means \pm SE $(n=3)$. Investigation days: $\diamond 11$ July, $\bigcirc 18$ August). PAR, photosynthetically active radiation.

tosynthesis rate with the increased light intensity except in Yunpoong, which suggests that it is the light saturation point (Fig. 1). The light saturation point in Yunpoong was around $400 \mu \mathrm{mol} \mathrm{m} \mathrm{m}^{-2}$. These results are consistent with those of previous studies [7-9], in which the light intensity for optimum net photosynthesis was around 200 to $400 \mu \mathrm{mol} \mathrm{m} \mathrm{s}^{-2}$ and the light saturation point in Yunpoong was $400 \mu \mathrm{mol} \mathrm{m} \mathrm{m}^{-2} \mathrm{~s}^{-1}$, whereas that for the other HTI-resistant and -susceptible Chunpoong was 200 $\mu \mathrm{mol} \mathrm{m} \mathrm{s}^{-2}$. Among the ginseng lines with the same light saturation point of $200 \mu \mathrm{mol} \mathrm{m} \mathrm{s}^{-1}$, the net photosynthesis rate at the light intensity of $200 \mu \mathrm{mol} \mathrm{m} \mathrm{s}^{-1}$ in July was highest in HTIR $3\left(4.2 \mu \mathrm{mol} \mathrm{CO} \mathrm{CO}^{-2} \mathrm{~s}^{-1}\right)$ and lowest in HTIR 1 (3.2 $\left.\mu \mathrm{mol} \mathrm{CO} \mathrm{m}^{-2} \mathrm{~s}^{-1}\right)$, Chunpoong $(3.1 \mu \mathrm{mol}$ $\left.\mathrm{CO}_{2} \mathrm{~m}^{-2} \mathrm{~s}^{-1}\right)$, and HTIR $2\left(1.9 \mu \mathrm{mol} \mathrm{CO} \mathrm{CO}_{2} \mathrm{~m}^{-2}\right)$, in that order. The net photosynthesis rate at the light saturation point in July was $3.7 \mu \mathrm{mol} \mathrm{CO}_{2} \mathrm{~m}^{-2} \mathrm{~s}^{-1}$ in Yunpoong, with a light saturation point of $400 \mu \mathrm{mol} \mathrm{m} \mathrm{s}^{-1}$. In August, the net photosynthesis rate at the light intensity of $200 \mu \mathrm{mol}$ $\mathrm{m}^{-2} \mathrm{~s}^{-1}$ was highest in HTIR 1 and HTIR $3(4.5 \mu \mathrm{mol} \mathrm{CO}$ 
$\mathrm{m}^{-2} \mathrm{~s}^{-1}$ ) among the ginseng lines with the light saturation point of $200 \mu \mathrm{mol} \mathrm{m} \mathrm{m}^{-2} \mathrm{~s}^{-1}$, and was similar in Chunpoong $\left(2.9 \mu \mathrm{mol} \mathrm{CO} \mathrm{C}^{-2} \mathrm{~s}^{-1}\right)$ and HTIR $2\left(2.8 \mu \mathrm{mol} \mathrm{CO} \mathrm{CO}^{-2} \mathrm{~s}^{-1}\right)$. The net photosynthesis rate at the light saturation point in August was $5.9 \mu \mathrm{mol} \mathrm{CO} \mathrm{C}^{-2} \mathrm{~s}^{-1}$ in Yunpoong, with a light saturation point of $400 \mu \mathrm{mol} \mathrm{m} \mathrm{m}^{-2}$. In the HTIresistant ginseng (Yunpoong and HTIR 1), the net photosynthesis rate in August increased remarkably compared to that in July, and only slightly increased in the other HTI-resistant lines (HTIR 2 and HTIR 3). On the other hand, no or little difference in the net photosynthesis rate was noted in the HTI-susceptible variety (Chunpoong) between July and August. These results indicate that photosynthesis may occur more readily at a high temperature in the HTI-resistant ginseng lines than in the HTI-susceptible lines whose photosynthesis rates between July and August did not differ. HTI occurs on ginseng plants that grow under a shade in which the canopy temperature remains at over $30^{\circ} \mathrm{C}$ for about a week [10]. The net photosynthesis rate in the HTI-resistant ginseng lines is not expected to decrease significantly at this temperature, however, because it was confirmed that the photosynthesis rate increased during the hot season. An [7] reported that the photosynthesis rate under the light intensity of $500 \mu \mathrm{mol} \mathrm{m} \mathrm{m}^{-2} \mathrm{~s}^{-1}$ increased in August rather than in July, regardless of the shading material such as the shading sheet, polyethylene net, and rice straw. This is consistent with the results of the authors' study in which the photosynthesis rate was higher in August than in July at the light intensity of $200 \mu \mathrm{mol} \mathrm{m} \mathrm{m}^{-2}$. On the other hand, Oh et al. [8] reported that the net photosynthesis rate in three-year-old Jakyungjong was highest in June and decreased thereafter toward July and August, regardless of the planting position (row). This seems to be similar to the result of the authors' study that the photosynthesis rate did not increase in August, unlike in July, in the HTIsusceptible variety (Chunpoong).

The changes in the stomatal conductance due to the light intensity are shown in Fig. 2. Among the ginseng lines with a light saturation point of $200 \mu \mathrm{mol} \mathrm{m} \mathrm{s}^{-1}$, the stomatal conductance at the light intensity of $200 \mu \mathrm{mol}$ $\mathrm{m}^{-2} \mathrm{~s}^{-1}$ in July was highest $\left(0.055 \mathrm{~mol} \mathrm{H}_{2} \mathrm{O} \mathrm{m}^{-2} \mathrm{~s}^{-1}\right)$ in HTIR 3 , and decreased in Chunpoong $\left(0.037 \mathrm{~mol} \mathrm{H}_{2} \mathrm{O} \mathrm{m}^{-2} \mathrm{~s}^{-1}\right)$, HTIR $1\left(0.031 \mathrm{~mol} \mathrm{H}_{2} \mathrm{O} \mathrm{m}^{-2} \mathrm{~s}^{-1}\right)$, and HTIR $2(0.017 \mathrm{~mol}$ $\left.\mathrm{H}_{2} \mathrm{O} \mathrm{m}^{-2} \mathrm{~s}^{-1}\right)$, in that order. In Yunpoong, which had a light saturation point of $400 \mu \mathrm{mol} \mathrm{m} \mathrm{m}^{-2} \mathrm{~s}^{-1}$, the stomatal conductance at the light intensity of $400 \mu \mathrm{mol} \mathrm{m} \mathrm{s}^{-2}$ in July was $0.038 \mathrm{~mol} \mathrm{H}_{2} \mathrm{O} \mathrm{m}^{-2} \mathrm{~s}^{-1}$. The stomatal conductance at the same light intensity of 200 or $400 \mu \mathrm{mol} \mathrm{m} \mathrm{m}^{-2}$ was significantly higher in HTIR $1\left(0.075 \mathrm{~mol} \mathrm{H}_{2} \mathrm{O} \mathrm{m}^{-2} \mathrm{~s}^{-1}\right)$,
HTIR $3\left(0.070 \mathrm{~mol} \mathrm{H}_{2} \mathrm{O} \mathrm{m}^{-2} \mathrm{~s}^{-1}\right)$, and Yunpoong (0.106 $\left.\mathrm{mol} \mathrm{H}_{2} \mathrm{O} \mathrm{m}^{-2} \mathrm{~s}^{-1}\right)$ in August than in July. No significant difference was noted in the stomatal conductance values in the HTI-resistant HTIR 2 line $\left(0.023 \mathrm{~mol} \mathrm{H}_{2} \mathrm{O} \mathrm{m}^{-2} \mathrm{~s}^{-1}\right)$ and the HTI-susceptible Chunpoong $\left(0.047 \mathrm{~mol} \mathrm{H}_{2} \mathrm{O} \mathrm{m}^{-2} \mathrm{~s}^{-1}\right)$ between July and August. The stomatal conductance is similarly elevated with the increase in the net photosynthesis rate, which is enhanced up to the light saturation point and sustained thereafter in the stationary phase $[7,8,11]$. On the other hand, the stomatal conductivity in Chloranthus glaber continued to increase steadily above the light saturation point [12].

The intercellular $\mathrm{CO}_{2}$ concentration influenced by the light intensity is related to the stomatal opening and closing; the lowered intercellular $\mathrm{CO}_{2}$ concentration causes the entry of $\mathrm{K}^{+}$and water into the guard cells from the mesohphyll cells, as a result of which the stoma opens so that the leaves absorb the atmospheric $\mathrm{CO}_{2}$ that is used for photosynthesis. Among the ginseng lines with a light saturation point of $200 \mu \mathrm{mol} \mathrm{m}^{-2} \mathrm{~s}^{-1}$, the intercellular $\mathrm{CO}_{2}$ concentration in July decreased most significantly to 139 $\mu \mathrm{mol} \mathrm{mol}{ }^{-1}$ in HTIR 2, and increased in HTIR 1 (217 $\left.\mu \mathrm{mol} \mathrm{mol}{ }^{-1}\right)$, Chunpoong $\left(251 \mu \mathrm{mol} \mathrm{mol}{ }^{-1}\right)$, and HTIR $3\left(257 \mu \mathrm{mol} \mathrm{mol}^{-1}\right)$, in that order (Fig. 3). In Yunpoong that had a light saturation point of $400 \mu \mathrm{mol} \mathrm{m} \mathrm{s}^{-1}$, the intercellular $\mathrm{CO}_{2}$ concentration decreased to $225 \mu \mathrm{mol}$ $\mathrm{mol}^{-1}$ in July. Among the ginseng lines with the light saturation point of $200 \mu \mathrm{mol} \mathrm{m} \mathrm{s}^{-1}$, the intercellular $\mathrm{CO}_{2}$ concentration in August decreased most significantly to $185 \mu \mathrm{mol} \mathrm{mol}^{-1}$ in HTIR 2 and increased in HTIR 3 (274 $\left.\mu \mathrm{mol} \mathrm{mol}{ }^{-1}\right)$, Chunpoong $\left(276 \mu \mathrm{mol} \mathrm{mol}{ }^{-1}\right)$, and HTIR $1\left(278 \mu \mathrm{mol} \mathrm{mol}^{-1}\right)$, in that order. In Yunpoong that had a light saturation point of $400 \mu \mathrm{mol} \mathrm{m} \mathrm{m}^{-2} \mathrm{~s}^{-1}$, the intercellular $\mathrm{CO}_{2}$ concentration decreased to $282 \mu \mathrm{mol} \mathrm{mol}^{-1}$ in August. These results indicate that the $\mathrm{CO}_{2}$ concentration at the light saturation point decreases more significantly in HTI-resistant ginseng lines than in HTI-susceptible ginseng line. This is probably because the HTI-resistant ginseng lines sustain photosynthesis even at above $25^{\circ} \mathrm{C}$, thus depriving the intercellular spaces of $\mathrm{CO}_{2}$ for photosynthesis, whereas photosynthesis is inhibited beyond such temperature in HTI-susceptible ginseng line.

The changes in the transpiration rate according to the light intensity are shown in Fig. 4. The transpiration rate in July was $0.83-0.96 \mathrm{~mol} \mathrm{H}_{2} \mathrm{O} \mathrm{m}^{-2} \mathrm{~s}^{-1}$ in Yunpoong, 0.50$0.52 \mathrm{~mol} \mathrm{H}_{2} \mathrm{O} \mathrm{m}^{-2} \mathrm{~s}^{-1}$ in HTIR 1, 0.27-0.65 $\mathrm{mol} \mathrm{H}_{2} \mathrm{O} \mathrm{m}^{-2} \mathrm{~s}^{-}$ ${ }^{1}$ in HTIR 2, 0.85-1.03 mol H $\mathrm{O} \mathrm{m}^{-2} \mathrm{~s}^{-1}$ in HTIR 3, 0.51$0.56 \mathrm{~mol} \mathrm{H}_{2} \mathrm{O} \mathrm{m}^{-2} \mathrm{~s}^{-1}$ in Chunpoong, respectively. The transpiration rate in August was 1.79-2.10 $\mathrm{mol} \mathrm{H}_{2} \mathrm{O} \mathrm{m}^{-2} \mathrm{~s}^{-1}$ in Yunpoong, 1.67-1.78 $\mathrm{mol} \mathrm{H}_{2} \mathrm{O} \mathrm{m}^{-2} \mathrm{~s}^{-1}$ in HTIR 1, 0.84- 
A
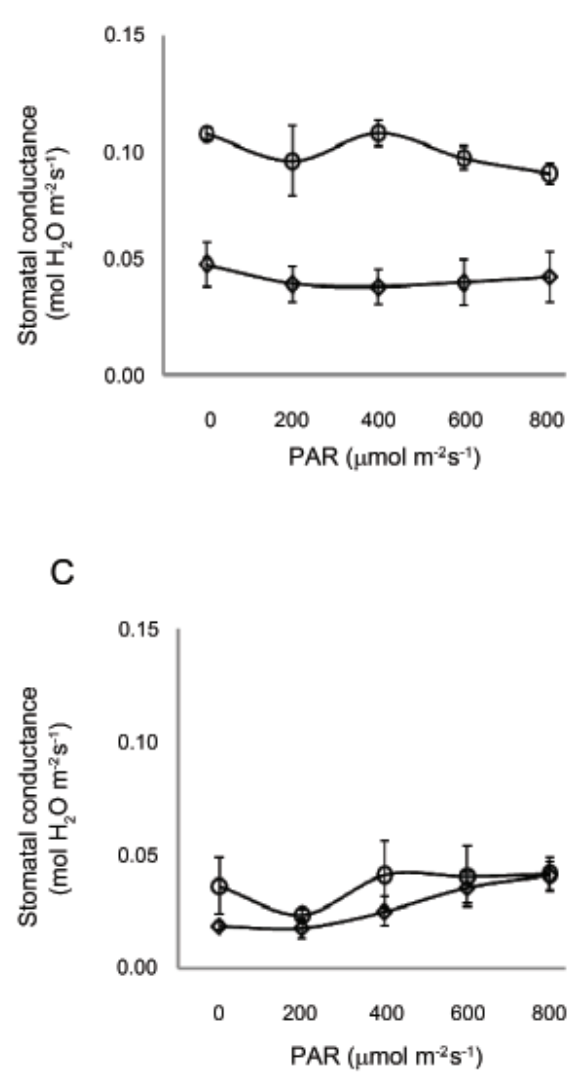

B

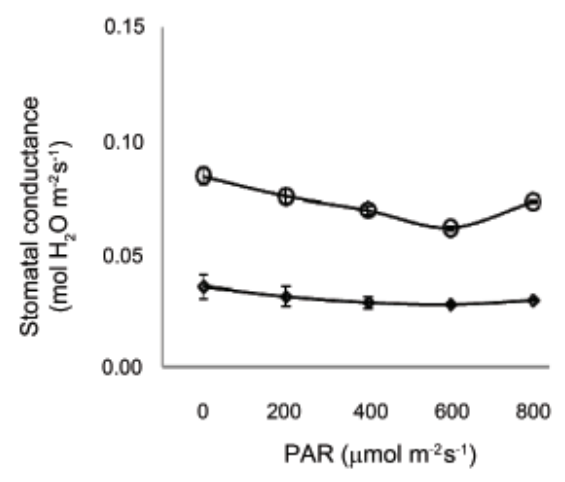

D

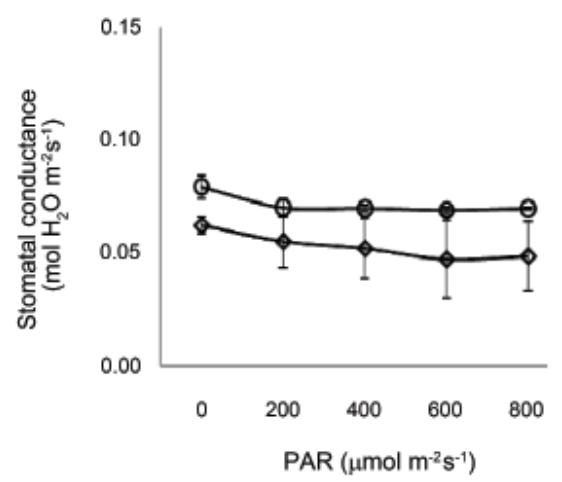

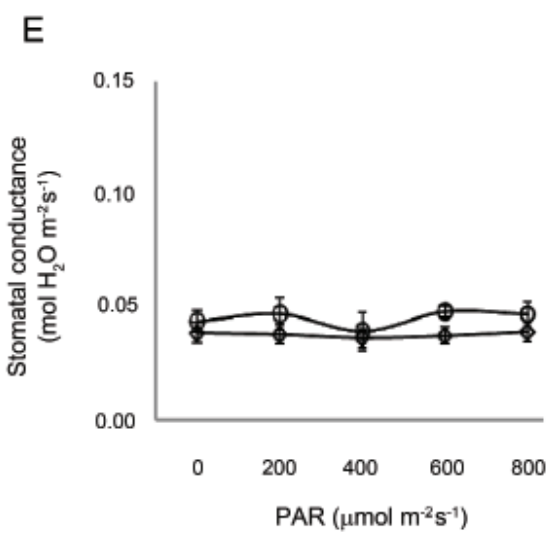

Fig. 2. Monthly stomatal conductance in the high temperature injury-resistant (A: Yunpoong, B: HTIR 1, C: HTIR 2, and D: HTIR 3), susceptible (E: Chunpoong) lines. The bars represent the means \pm SE $(n=3)$. Investigation days: $\diamond 11$ July, $\bigcirc 18$ August). PAR, photosynthetically active radiation.

$1.02 \mathrm{~mol} \mathrm{H}_{2} \mathrm{O} \mathrm{m}^{-2} \mathrm{~s}^{-1}$ in HTIR 2, 1.47-1.65 $\mathrm{mol} \mathrm{H}_{2} \mathrm{O} \mathrm{m}^{-2} \mathrm{~s}^{-1}$ in HTIR 3, 1.15-1.35 mol H $\mathrm{O} \mathrm{m}^{-2} \mathrm{~s}^{-1}$ in Chunpoong. These results show that the transpiration rates in all the tested ginseng lines were higher in August than in July, except in Yunpoong and HTIR 3, in which the transpiration rate was high both in July and August. The transpiration rate was increased remarkably in August in HTIR 1 but only slightly in HTIR 2. In Chunpoong, the transpiration rate was also higher in August than in July, but was not as high as in the HTI-resistant lines. The higher increase in the transpiration rate in August than in July may be related to the cooling of the ginseng leaves under the shade with a high canopy temperature due to the evaporation of water molecules from the surface openings (stomata) [7].

In this study, it was confirmed that the light saturation point in Yunpoong was $400 \mu \mathrm{mol} \mathrm{m} \mathrm{m}^{-2} \mathrm{~s}^{-1}$, and $200 \mu \mathrm{mol}$ 


\section{A}

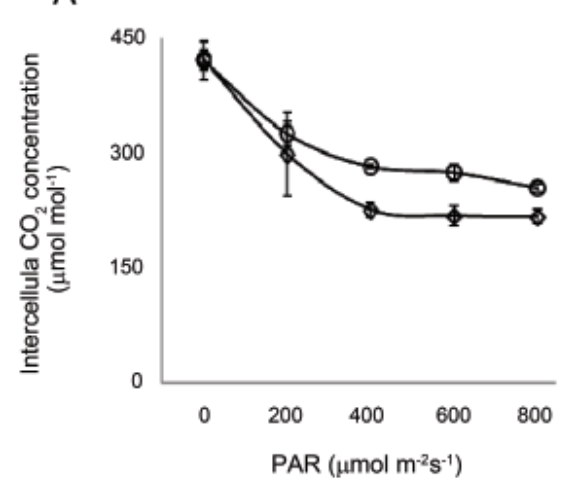

C

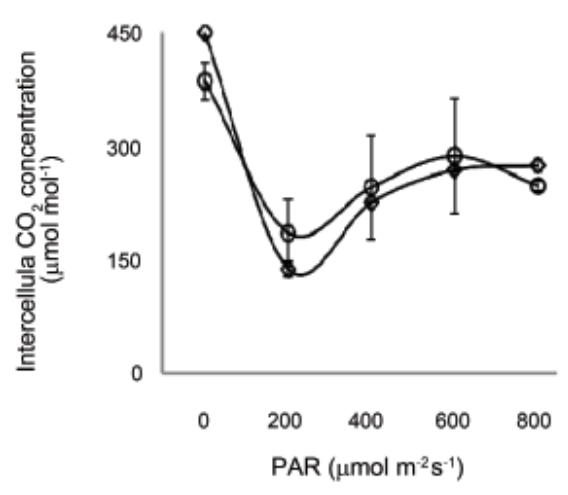

B

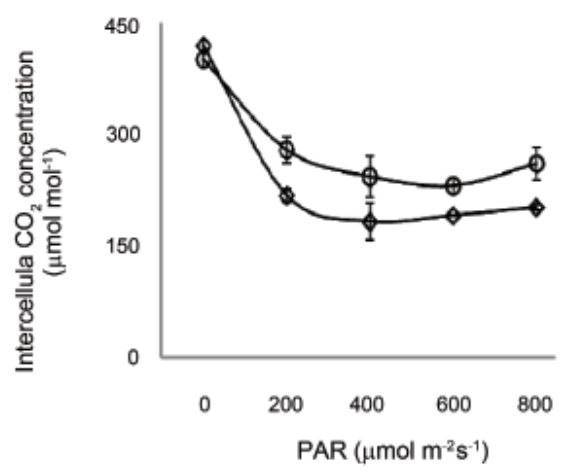

D

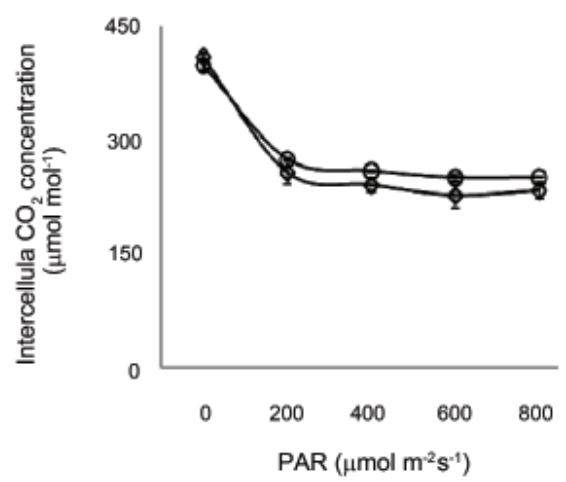

E

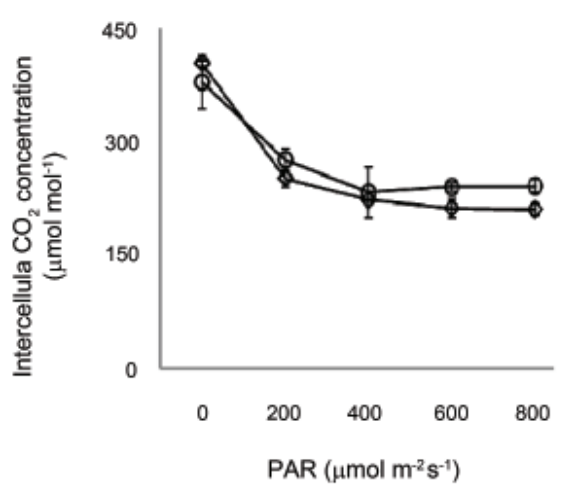

Fig. 3. Monthly intercellular $\mathrm{CO}_{2}$ concentration in the high temperature injury- resistant (A: Yunpoong, B: HTIR 1, C: HTIR 2, and D: HTIR 3), susceptible (E: Chunpoong) lines. The bars represent the means $\pm S E(n=3)$. Investigation days: $\diamond 11$ July, $\bigcirc 18$ August). PAR, photosynthetically active radiation.

$\mathrm{m}^{-2} \mathrm{~s}^{-1}$ in the other tested ginseng lines. These suggest that to properly growth the ginseng plant in Yunpoong, the net photosynthesis rate there should be enhanced by increasing the light transmission rate there before the hot season. Lee [6] reported that the net photosynthesis rate was highest in Yunpoong among the ginseng cultivars, presumably because of its more efficient $\mathrm{CO}_{2}$ exchange ability due to the greater stomatal distribution on its leaves, even though they were smaller than those in the other ginseng lines. Also, Yunpoong has a large leaf area per plant because of its many leaflets, so it could efficiently produce organic materials (by photosynthesis), unlike other ginseng varieties and/or lines, which contributes to its heavier ginseng root weight. Plant respira- 
A

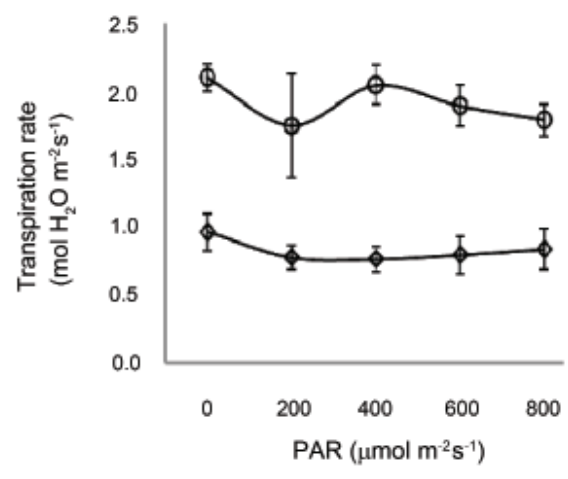

C

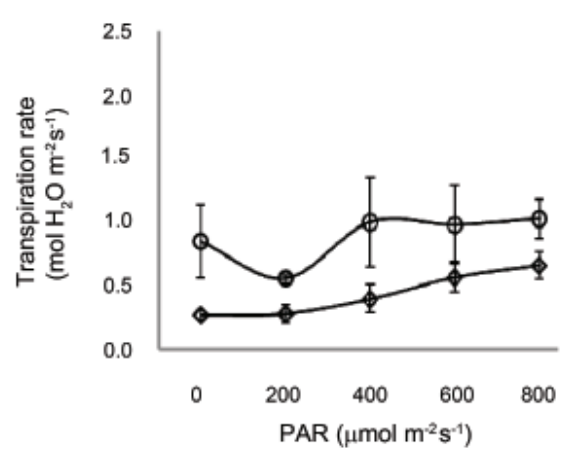

B
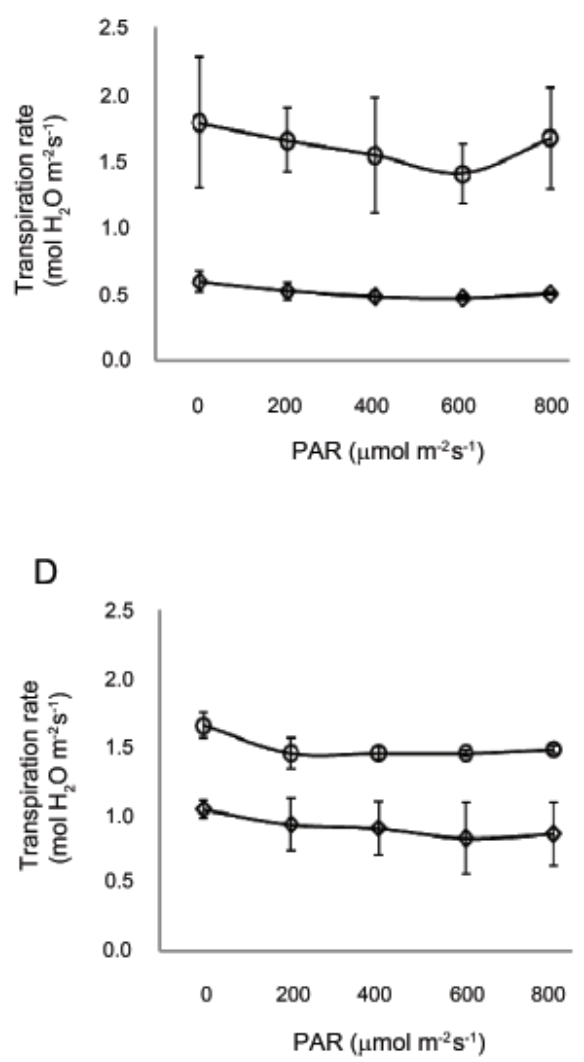

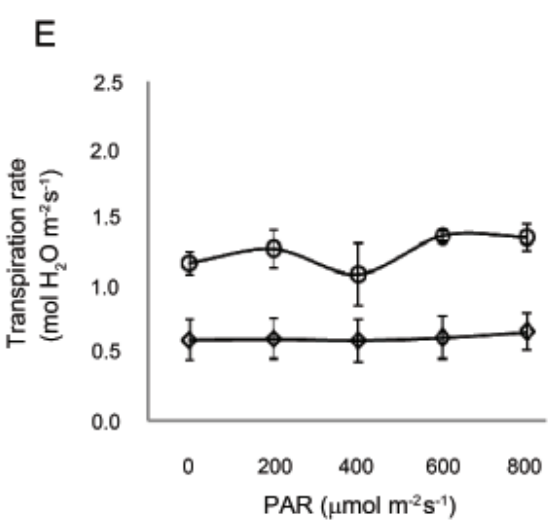

Fig. 4. Monthly transpiration rates in the high temperature injury-resistant (A: Yunpoong, B: HTIR 1, C: HTIR 2, and D: HTIR 3), susceptible (E: Chunpoong) lines. The bars represent the means \pm SE $(n=3)$. Investigation days: $\diamond 11$ July, $\bigcirc 18$ August). PAR, photosynthetically active radiation.

tion involves the oxidation of organic materials such as carbohydrates to produce chemical energy, which is used for growth respiration and maintenance respiration for the plant's growth and survival, respectively. Especially, the remarkable increase in the maintenance respiration due to the excessive development of non-photosynthesizing organs such as stems decreased the plant yield [13]. Yunpoong is a ginseng variety with multiple stems at- tached to numerous leaflets that overlap, so they receive insufficient light for full photosynthesis. This may lead to the poor accumulation of nutritional substances, which has been suggested as one of the reasons why Yunpoong has a high percentage of inside cavities in the red ginseng that is manufactured from raw ginseng [14].

Lee et al. [10] and Lee et al. [15] reported that the relative light maximum in the HTI-resistant ginseng lines 
used in this study increased more significantly in August than in July, but decreased in the HTI-susceptible such as Chunpoong. The maximum relative light is high with low photo inhibition in the HTI-resistant ginseng lines, and low with high photo inhibition in Chunpoong, which inhibit photosynthesis. Also, the distribution of cuticle layers, thickness of cuticles on adaxial and abaxial surfaces, and longitudinal stomatal lengths are more profoundly developed on the lines resistance such as HTIR 1, 2 and 3 than on the susceptible line Chunpoong.

In this study, the net photosynthesis rate of the HTIresistant line HTIR 2 was lower in July and slightly higher in August than in Chunpoong; but the decrease in the intercellular $\mathrm{CO}_{2}$ concentration in HTIR 2 was fastest among the tested ginseng lines. This suggests that this ginseng line may utilize atmospheric $\mathrm{CO}_{2}$ most efficiently under continuous irradiation of the optimum light intensity, thus preventing transpiration via stomatal closing due to the increase in the intercellular $\mathrm{CO}_{2}$ concentration with the irradiation of excessive light intensity. Therefore, all these results can be used to provide basic information for the selection of HTI-resistant ginseng lines and the application of cultural practices that promote the efficient growth of ginseng lines based on their photosynthetic characteristics.

\section{ACKNOWLEDGEMENTS}

This work was supported by a grant from the NextGeneration BioGreen 21 Program (Plant Molecular Breeding Center no. SA00003878), Rural Development Administration, Republic of Korea.

\section{REFERENCES}

1. Lee JC, Cheon SK, Kim YT, Kim SD, Ahn SB. Studies on the optimum light intensity for the growth of Panax ginseng. II. Study on the difference of the optimum light intensity for the growth of the ginseng plant according to its root age. Korean J Ginseng Sci 1982;6:149-153.

2. Lee SS, Kim JM, Cheon SK, Kim YT. Relationship between environmental conditions and the growth of ginseng plant in the field. II. Light intensity under a shading material and photosynthesis. Korean J Crop Sci 1982;27:169-174.
3. Lee $\mathrm{CH}$. Environmental effects on the plant growth of ginseng (Panax spp.): light and temperature orientation [dissertation]. Seoul: Kyung Hee University, 1983.

4. Hyun DY, Hwang JK, Choi SY, Jo JS. Photosynthetic characteristics of Panax ginseng C.A. Meyer. I. Photosynthetic response to light intensity and leaf temperature. Korean J Ginseng Sci 1993;17:240-245.

5. Lee SS, Cheon SR, Lee CH. Comparison of photosynthetic rates of Panax species and cultivars. Korean J Crop Sci 1987;32:157-162.

6. Lee SS. Characteristics of photosynthesis among new cultivars of ginseng (Panax ginseng C.A. Meyer). J Ginseng Res 2002;26:85-88.

7. An YN. Microclimate, production, and quality of ginseng (Panax ginseng C.A. Meyer) under different shade structures [dissertation]. Daegu: Yeungnam University, 2010.

8. Oh DJ, Lee CY, Kim SM, Li GY, Lee SJ, Hwang DY, Son HJ, Won JY. Effects of chlorophyll fluorescence and photosynthesis characteristics by planting positions and growth stage of Panax ginseng C.A. Meyer. Korean J Med Crop Sci 2010;18:65-69.

9. Lee CY. Characteristics of photosynthesis with growing stages by different shading materials in Panax ginseng C. A. Meyer. Korean J Med Crop Sci 2007;15:276-284.

10. Lee JS, Lee JH, Ahn IO. Characteristics of resistant lines to high-temperature injury in ginseng (Panax ginseng C.A. Meyer). J Ginseng Res 2010;34:274-281.

11. Won JY, Lee CY, Oh DJ, Kim SM. Changes of chlorophyll fluorescence and photosynthesis under different shade materials in Korean ginseng (Panax ginseng C.A. Meyer). Korean J Med Crop Sci 2008;16:416-420.

12. Won JY, Lee CY. Characteristic of photosynthesis and dry matter production of Liriope platyphylla $\mathrm{W}_{\mathrm{ANG}}$ et $\mathrm{T}_{\mathrm{ANG}}$. Korean J Med Crop Sci 2002;10:82-87.

13. Rho YD. Photosynthesis and dry matter production efficiency of crops. Korean Soybean Soc 1986;3:10-15.

14. Lee JC. Characteristics of aboveground and red ginseng quality of polystem ginseng (Panax ginseng C.A. Meyer). Korean J Med Crop Sci 1996;4:255-260.

15. Lee JS, Lee KH, Lee SS, Kim ES, Ahn IO, In JG. Morphological characteristics of ginseng leaves in high-temperature injury resistant and susceptible lines of Panax ginseng Meyer. J Ginseng Res 2011;35:449-456. 